\title{
The Euro Group's Informality and locus standi before the European Court of Justice: Council v. K. Chrysostomides \& Co. and Others
}

Giacomo Rugge ${ }^{\star}$

Max Planck Institute for Comparative Public Law and International Law, Heidelberg, Germany

rugge@mpil.de

Abstract

$\begin{array}{ll}\text { Keywords } & 918\end{array}$

I. Introduction $\quad 918$

$\begin{array}{ll}\text { II. Factual and Legal Background } & 919\end{array}$

III. The Judgment of the Court $\quad 922$

IV. The Euro Group as an 'Institution' of the EU under Art. 340 TFEU 924

1. Intergovernmental Nature $\quad 924$

2. Informality and the Lack of Own Competences 927

V. The Principle of Effective Legal Protection 930

VI. Conclusion $\quad 934$

\begin{abstract}
This article provides an analysis of the recent European Court of Justice's (ECJ) judgment in Council v. K. Chrysostomides E Co. and Others. After the Cypriot financial and banking crisis of 2012-13, the case raised the issue as to whether the Euro Group could be considered as an 'institution' for the purposes of non-contractual liability under Art. 340 para. 2 of the Treaty on the Functioning of the European Union (TFEU). The Court replied in the negative, offering a set of arguments on the nature and role of the Euro Group within the European economic constitution and on the legal protection of individuals vis-à-vis austerity measures. The article summarises and criticises those arguments, showing how this judgment of the Court has made the Euro Group essentially immune against judicial proceedings, despite its pivotal role in the management of European economic and monetary issues.
\end{abstract}

* The author is Senior Research Fellow at the Max Planck Institute for Comparative Public Law and International Law. I am thankful to Desirée C. Schmitt, Lea Berger and Diane Fromage as well as the anonymous reviewers for valuable suggestions. Any mistakes remain solely my own. 


\section{Keywords}

Euro Group - Cypriot financial and banking crisis - informality - noncontractual liability - effective legal protection.

\section{Introduction}

On 16 December 2020, the European Court of Justice, sitting as Grand Chamber, delivered an important judgment in Council v. K. Chrysostomides $\mathcal{E}$ Co. and Others. ${ }^{1}$ The judgment resulted from different appeals against two previous decisions by the General Court (GC). ${ }^{2}$ The appeals were brought by the Council, on the one hand, and by a group of uninsured depositors, shareholders, and bondholders, on the other hand. The Council asked the ECJ to set aside those parts of the contested decisions in which the General Court had declared admissible several actions for non-contractual liability against the Euro Group. The other appellants, instead, asked the Court to grant them a compensation for the damages allegedly caused by the Euro Group in the management of the 2012-13 Cyprus financial and banking crisis. The judgment is intricate and multifaceted. I have therefore chosen to focus on its most important and problematic part: The Court's findings about the Council's appeal and, in particular, those about the nature and role of the Euro Group in the constitutional structure of the Economic and Monetary Union (EMU).

As a confirmation of my choice, one may simply consider that Advocate General (AG) Pitruzzella's opinion was entirely devoted to clarifying the nature and role of the Euro Group and to answering the following question: Can the Euro Group be considered as an 'institution' for the purposes of an action for damages (Art. 340 para. 2 TFEU)? Or, better put, can individuals bring the Euro Group before the Court of Justice of the European Union (CJEU) to obtain compensation for the damages supposedly caused by its unlawful acts or conduct? ${ }^{3}$ Drawing extensively on the Advocate General's

1 ECJ, Council v. K. Chrysostomides E Co. and Others, judgment of 16 December 2020, case no. C-597/18 P, ECLI:EU:C:2020:1028. For a first analysis of this judgment, Menelaos Markakis and Anastasia Karatzia, 'The Final Act on the Eurogroup and Effective Judicial Protection in the EU: Chrysostomides', EU Law Live (22 December 2020). See also 'ECJ upholds dismissal of actions following aid requirements to restructure banks in Cyprus', EU Focus 400 (2021), $6 \mathrm{f}$.

2 GC, Chrysostomides, K. E Co. and Others v. Council and Others, judgment of 13 July 2018, case no. T-680/13, ECLI:EU:T:2018:486; GC, Bourdouvali and Others v. Council and Others, judgment of 13 July 2018, case no. T-786/14, ECLI:EU:T:2018:487.

3 ECJ, Council v. K. Chrysostomides \& Co. and Others, opinion of AG Pitruzzella of 28 May 2020, case no. C-597/18 P, ECLI:EU:C:2020:390, paras 3 and 19. 
opinion, the ECJ gave a negative answer to these questions; and this has engendered the almost complete absence of judicial remedies against the actions and conduct of the Euro Group. The Court's findings are surprising not only because they disregard the considerable political influence accrued by the Euro Group in economic and monetary matters, but also because they are at odds with the most recent case-law on liability claims in other fields of EU law.

With this article, I will elaborate on these observations. To that end, I will first sketch out the factual and legal background to the case (II.) and summarise the main findings of the ECJ (III.). Then, I will provide some critical comments, organising them around two main thematic blocks. The first block will address the Court's arguments about the nature and role of the Euro Group in the European legal order (IV. a. and IV.b.). The second block will instead focus on the Court's response to the arguments concerning a possible infringement of the principle of effective judicial protection (V.). I will eventually offer some concluding remarks (VI.).

\section{Factual and Legal Background}

Between 2012 and 2013, Cyprus experienced significant financial difficulties, especially due to its exposure in the Greek economy. These difficulties hit two banks with particular intensity (Laïki and Bank of Cyprus) and eventually led to the Cypriot authorities filing a request to the Euro Group for financial assistance. At the end of June 2012, the Euro Group declared that its Members were in favour of granting such assistance through the European Stability Mechanism (ESM) and under strict conditionality. Representatives of the 'troika' (as formed by the European Commission, the European Central Bank (ECB), and the International Monetary Fund) and the Cypriot authorities began to negotiate a draft memorandum of understanding (MoU). On 25 March 2013, in the wake of fraught negotiations, the Euro Group released a statement, confirming the attainment of a political agreement between the Eurozone Member States and Cyprus. ${ }^{4}$ This statement included eight points that defined, in general terms, the main conditions for the authorisation of financial assistance. On 26 April 2013, the Commission (on behalf of the ESM) and Cyprus signed a memorandum of understanding, which concretised those eight points. Shortly thereafter, the Cypriot parliament approved the MoU.

4 Euro Group, 'Eurogroup Statement on Cyprus’, (25 March 2013). 
The Euro Group's statement and the following memorandum of understanding provided, among other things, that the money granted through the financial assistance programme could not be used to recapitalise Laiki and the Bank of Cyprus; and that the two failing banks had to be rescued through a bail-in programme, i. e. with full contribution of uninsured depositors (holders of deposits whose value exceeded 100,000 Euros), shareholders, and bondholders. Needless to say, this approach caused relevant financial losses for a significant number of individuals and companies, who began to resort to courts in order to seek relief. Some actions reached the European judiciary and gave rise to decisions of constitutional relevance, such as the twin judgments in Ledra and Mallis. ${ }^{5}$ The former judgment arose from a set of actions for non-contractual liability deriving from the implementation of the MoU of 26 April 2013; the latter, instead, stemmed from a set of actions for annulment against the Euro Group's statement of 25 March 2013.

In Ledra, the Court reaffirmed the maxim that, although the ESM Treaty falls outside the European legal order, the tasks allocated to the Commission by that Treaty oblige it to ensure that the MoUs concluded by the ESM are consistent with European Union (EU) law, including the Charter of Fundamental Rights (CFR). The Commission may therefore incur non-contractual liability for those unlawful acts or conduct committed while working under the purview of the ESM. ${ }^{6}$ The ECJ, however, dismissed the actions in the substance, as the applicants had not established the first condition of a successful action for non-contractual liability, i. e. the existence of 'a sufficiently serious breach of a rule of law intended to confer rights on individuals'. ${ }^{7}$ In Mallis, instead, the Court ruled out the possibility of filing actions for annulment against statements of the Euro Group. In particular, the Court held that, 'as the Eurogroup is not a decision-making body, a statement by it cannot be regarded as a measure intended to produce legal effects with respect to third parties'. It concluded by stating that, due to its informal nature and its lack of legal personality, the Euro Group does not qualify as 'a body, office or agency of the European Union within the meaning of Art. 263 TFEU'. ${ }^{8}$ Therefore, the Court dismissed the actions as unfounded.

5 ECJ, Ledra Advertising v. Commission and ECB, judgment of 20 September 2016, case no. C-8/15 P, ECLI:EU:C:2016:701; ECJ, Mallis and Malli v. Commission and ECB, judgment of 20 September 2016, case no. C-105/15 P, ECLI:EU:C:2016:702. On these judgments, René Repasi, 'Judicial Protection Against Austerity Measures in the Euro Area: Ledra and Mallis', CML Rev. 54 (2017), 1123-1155.

6 ECJ, Ledra (n. 5), para. 67.

7 ECJ, Ledra (n. 5), para. 65.

8 ECJ, Mallis (n. 5), paras 49 and 61. 
It is against this background that the case Chrysostomides $\mathcal{E} C$. began to take shape. The General Court was indeed asked to rule on two sets of actions for non-contractual liability against the Euro Group and other defendants. Before addressing the merits, however, the GC had to decide on a plea of inadmissibility filed by the Council, according to which the Euro Group was not an 'institution' under Art. 340 para. 2 TFEU and therefore lacked passive legal standing in liability claims. The General Court rejected this plea. In particular, following the standard two-pronged test, it found that the Euro Group 'is a body of the Union formally established by the Treaties' and is 'intended to contribute to achieving objectives of the Union'. ${ }^{9}$ In the words of the GC:

'Article 137 TFEU and Protocol No 14 [...] on the Euro Group [...], inter alia, for the existence, the composition, the procedural rules and the functions of the Euro Group. In that last regard, Article 1 of that protocol provides that the Euro Group is to meet "to discuss questions related to the specific responsibilities [the ministers composing it] share with regard to the single currency". Those questions concern, under Article 119(2) TFEU, the activities of the European Union for the purposes of the objectives set out in Article 3 TEU, which include the establishment of an economic and monetary union whose currency is the Euro. It follows that the Euro Group is a body of the Union formally established by the Treaties and intended to contribute to achieving the objectives of the Union. The acts and conduct of the Euro Group in the exercise of its powers under EU law are therefore attributable to the European Union. ${ }^{10}$

After declaring the actions admissible, the General Court dismissed them on other grounds. In particular, it concluded that the applicants had not succeeded in demonstrating an infringement of the right to property, of the principle of protection of legitimate expectations, or of the principle of equal treatment. The Council, however, considered that the reasoning of the General Court did not 'correspond neither to the Treaties nor to the spirit and the letter of the case-law of the Court of Justice on this matter'. ${ }^{11}$ It therefore decided to appeal, asking the ECJ to set aside those parts of the judgment where the General Court had concluded that the acts of the Euro Group may

9 With regard to non-contractual liability, Art. 340 TFEU provides the following: 'The Union shall, in accordance with the general principles common to the laws of the Member States, make good any damage caused by its institutions or by its servants in the performance of their duties.' According to settled case-law, the meaning of 'institution' under Art. 340 TFEU is broader than that of other Treaty provisions, notably Art. 13 TEU. In these terms, ECJ, Chrysostomides (n. 1), para. 80 (and the case-law cited therein).

10 GC, Chrysostomides (n. 2), para. 113; GC, Bourdowvali (n. 2), para. 109.

11 Council of the European Union, 'Appeal of the Council against Judgment in Case T-680/ 13', (SGS18/07677, 21 September 2018), para. 9 f. 
entail the non-contractual liability of the Union. The Council's appeals gave rise to the judgment of past 16 December, which I will summarise and criticise in the two upcoming sections.

\section{The Judgment of the Court}

The part of the judgment that is of interest here stretches from paragraphs 64 to 98. The underlying issue was whether the General Court had erred in law in affirming that 'the acts and conduct of the Euro Group in the exercise of its powers under EU law are [...] attributable to the European Union' for the purposes of actions for non-contractual liability. In its appeals, the Council challenged these findings, maintaining that the Euro Group does not fulfil the first condition for being considered an institution under Art. 340 TFEU (i. e. being established by the Treaty), ${ }^{12}$ since it is just 'an informal gathering of ministers of the [Eurozone] the only function of which is to discuss questions related to the specific responsibilities that the ministers share with regard to the single currency'. ${ }^{13}$ The respondents, instead, held the view that the Euro Group had been 'formalised by the Treaty of Lisbon which attached Protocol No 14 [on the Euro Group] to the FEU Treaty'. ${ }^{14}$

The ECJ found the GC's reasoning wanting and brought three arguments against it. First, the Court held that, although the Treaty of Lisbon had formalised the existence of the Euro Group, the Treaty had not changed the Euro Group's 'intergovernmental nature in the slightest'. ${ }^{15}$ Secondly, the Court highlighted that the Euro Group is characterised by its informality, 'which [...] can be explained by the purpose pursued by its creation of endowing economic and monetary union with an instrument of intergovernmental coordination but without affecting the role of the Council - which is the fulcrum of the European Union's decision-making process in economic matters - or the independence of the ECB' ${ }^{16}$ Finally, the Court maintained that the Euro Group has no competences of its own in the EU legal order, as its meetings are devoted to 'questions related to the specific responsibilities that the ministers of the [Eurozone] share with regard to the single currency - responsibilities which they owe solely on account of their competence at

12 Council of the European Union (n. 11), para. 27.

13 ECJ, Chrysostomides (n. 1), para. 68.

14 ECJ, Chrysostomides (n. 1), para. 75.

15 ECJ, Chrysostomides (n. 1), para. 87.

16 ECJ, Chrysostomides (n. 1), para. 88. 
national level'.17 On account of these arguments, the Court reached the conclusion that the Euro Group is not a body of the Union established by the Treaties, ${ }^{18}$ thereby ruling out that it may incur non-contractual liability for its acts and conduct.

In the paragraphs from 91 to 98, the Court sought to dispel the GC's statement that denying the possibility of bringing actions for non-contractual liability against the Euro Group would lead to a violation of the right to an effective judicial protection, as laid down in Art. 47 CFR. To this end, the Court highlighted the possibility for individuals to bring actions for noncontractual liability against the Council, the Commission, and the ECB for those acts and conduct through which these institutions concretise and implement austerity measures agreed upon by the Euro Group. ${ }^{19}$ The Court pointed at two possible routes. First, individuals could have based their actions on Council Decision 2013/236 addressed to Cyprus and containing the cornerstones of its macroeconomic adjustment programme. ${ }^{20}$ Secondly, the Court reminded that, according to Pringle and Ledra, ${ }^{21}$ the Commission and the ECB may also be sued for allegedly unlawful acts and conduct at the time of the negotiation and signing of an MoU. As the Court stated, the Commission 'retains, in the context of its participation in the activities of the Euro Group, its role of guardian of the Treaties. It follows that any failure on its part to check that the political agreements concluded within the Euro Group are in conformity with EU law is liable to result in non-contractual liability of the European Union'. ${ }^{22}$

Therefore, the Court upheld the appeals of the Council and set aside the GC's judgments insofar as they declared the actions for damages against the Euro Group admissible.

17 ECJ, Chrysostomides (n. 1), para. 89.

18 In this respect, it bears noting that the Court cites the relevant case-law in two different ways. In para. 80, it states that 'the term "institution" within the meaning of [Art. 340 TFEU] encompasses not only the EU institutions listed in Art. 13(1) TEU but also all the EU bodies, offices and agencies that have been established by or under the Treaties and are intended to contribute to the achievement of the European Union's objectives' (emphasis added). In para. 86, however, the two words 'or under' disappear and the Court returns to the old formulation 'established by the Treaties'. Indeed, including the preposition 'under' would have probably broadened the scope of Art. 340 TFEU and made it more difficult for the Court to claim that the Euro Group falls outside the EU primary law framework.

19 ECJ, Chrysostomides (n. 1), para. $93 \mathrm{f}$.

20 Decision 2013/236/EU of 25 April 2013 addressed to Cyprus on specific measures to restore financial stability and sustainable growth, OJ $2013 \mathrm{~L}$ 141/32.

21 ECJ, Pringle, judgment of 27 November 2012, case no. C-370/12, ECLI:EU:C:2012:756, para. 163; ECJ, Ledra (n. 5), para. 57.

22 ECJ, Chrysostomides (n. 1), para. 96. 


\section{The Euro Group as an 'Institution' of the EU under Art. 340 TFEU}

\section{Intergovernmental Nature}

To begin with, the Court emphasises the intergovernmental nature of the Euro Group. Unfortunately, though, it does not explain how this argument is meant to weigh on its findings. In particular, it does not provide any justification as to why the Euro Group's intergovernmental nature should exclude the possibility for individuals to initiate judicial proceedings for non-contractual liability. And the most obvious objection to this argument is that intergovernmentalism characterises other European institutions and bodies, the most prominent one being the European Council. ${ }^{23}$ Even though no action for non-contractual liability has yet been brought against this institution, ${ }^{24}$ it is genuinely doubtful that the Court would ever declare such an action inadmissible on the grounds that the European Council has an intergovernmental nature - especially after the Treaty of Lisbon included it among the 'Union's institutions' as listed in Art. 13 Treaty on European Union (TEU). ${ }^{25}$ Arguably, intergovernmentalism alone cannot release the Euro Group from non-contractual liability. There must be something else; something that the Court does not spell out.

To obtain clarity on this part of the judgment, it is useful to turn to the opinion of AG Pitruzzella, to which the Court refers rather extensively. ${ }^{26}$ And indeed the opinion clarifies that when the Court speaks of the Euro Group's 'intergovernmental nature', it is in fact implying that the Euro Group is external to the institutional framework of the EU. ${ }^{27}$ Such a reading would

23 In fact, intergovernmentalism has always been part of the governance methods of the EU. On this theme, locus classicus is J.H.H. Weiler, The Constitution of Europe: 'Do the New Clothes Have an Emperor?' and Other Essays on European Integration (Cambridge: Cambridge University Press 1999), 276 f. and 279-282.

24 In actuality, an action for non-contractual liability was brought against the European Council in 2003. However, the General Court applied a different, more restrictive concept of 'institution' than the one recalled here and decided to dismiss the action. In particular, the GC stated that the European Council was not 'an institution of the Community within the meaning of Article 7 EC' and 'only the conduct of an institution of the Community [could] give rise to the non-contractual liability of the Community'. See GC, Krikorian and Others v. Parliament and Others, order of 17 December 2003, case no. T-346/03, ECLI:EU:T:2003:348, para. 17.

25 In this sense, Koen Lenaerts, Ignace Maselis and Kathleen Gutman, EU Procedural Law (Oxford: Oxford University Press 2014), 497 (para. 11.20); Marc Jacob and Matthias Kottman, 'Art. 340 AEUV' in: Eberhard Grabitz, Meinhard Hilf and Martin Nettesheim (eds), Das Recht der Europäischen Union (München: C. H. Beck 2015), para. 70.

26 ECJ, Chrysostomides (n. 1), para. 84.

27 ECJ, Chrysostomides, opinion of AG Pitruzzella (n. 3), para. $105 \mathrm{f}$. 
explain the incidental reference in para. 84, where the ECJ states that 'the Euro Group was created as an intergovernmental body - outside the institutional framework of the European Union' ${ }^{28}$ If that is so, the Court has made a twofold mistake. It has misconstrued the changes brought about by the Treaty of Lisbon; and it has failed to take account of the profound, sweeping transformation experienced by the European economic constitution, including the Euro Group, on account of the European debt crisis. ${ }^{29}$ This is not the place to undertake an analysis of such intricate topics. I will thus confine myself to two brief considerations. The one is textual and systematic in character, the other deals with the political reality of the Euro Group.

As for the first consideration, Art. 5 TFEU prescribes that Member States 'shall coordinate their economic policies within the Union'. This means that the economic policy coordination is a genuine 'supporting competence' of the EU. Although such a competence cannot replace those of the Member States, the actions carried out by the EU complement and reinforce those of the Member States. ${ }^{30}$ In this regard, Art. 5 TFEU adds that 'specific provisions shall apply to those Member States whose currency is the euro'. Among these provisions is Art. 137 TFEU, which acknowledges the Euro Group as the body where the ministers of the Eurozone are meant to discuss matters of common concern, especially (but not only) the strengthening of the coordination and surveillance of their budgetary discipline and the formulation of economic policy guidelines. ${ }^{31}$ Furthermore, Art. 137 TFEU refers to Protocol (No 14), which enshrines the desire of the High Contracting Parties to formalise the Euro Group in order 'to develop ever-closer coordination of economic policies within the euro area'. This makes the Euro Group statutorily involved in the exercise of a supporting competence of the Union (Art. 5 TFEU) and, therefore, a component of the European institutional framework.

28 ECJ, Chrysostomides (n. 1), para. 84.

29 On the transformation of the European economic constitution, Herwig C. H. Hofmann and Katerina Pantazatou, 'The Transformation of the European Economic Constitution' in: Herwig C. H. Hofmann, Katerina Pantazatou and Giovanni Zaccaroni (eds), The Metamorphosis of the European Economic Constitution (Cheltenham: Edward Elgar Publishing), 2-24; Michael Ioannidis, 'Europe's New Transformations: How the EU Economic Constitution Changed During the Eurozone Crisis', CML Rev. 53 (2016), 1237-1282. On the resulting evolution of the Euro Group, Roberto Baratta, 'Diritto e prassi evolutiva dell'Eurogruppo', Il Diritto dell'Unione Europea (2015), 493-521; Paul Craig, 'The Eurogroup, Power and Accountability', ELJ 23 (2017), 234-249; Luuk van Middelaar, Alarums E Excursions: Improvising Politics on the European Stage (Newcastle upon Tyne: Agenda Publishing 2019), 194-196.

30 Roberto Adam and Antonio Tizzano, Manuale di diritto dell'Unione Europea (3rd edn, Torino: Giappichelli 2020), $441 \mathrm{f}$.

31 Moreover, the Treaties provide that the Member States' economic policies are 'a matter of common interest' (Art. 121(1) TFEU) and shall therefore be conducted 'with a view to contributing to the achievement of the objectives of the Union'. 
As for the second consideration, the Euro Group enjoys centre stage in 'all major initiatives relating to the euro area, broadly conceived, which cover structural adjustment, macroeconomic planning, negotiation with states in receipt of aid from the ESM, and aspects of banking union' ${ }^{32}$ In such a context, it acts as a 'clearing house' for interests specific to the Eurozone, often giving rise to common positions distinct from the assessments of the Economic and Financial Affairs Council (ECOFIN). ${ }^{33}$ So much so that, in the ill-fated decision on a new settlement for the United Kingdom before the Brexit referendum, the negotiating parties inserted a paragraph stating that the Euro Group 'shall respect the powers of the Council as an institution upon which the Treaties confer legislative functions and within which Member States coordinate their economic policies'. ${ }^{34}$ The Euro Group could acquire such a pivotal role through an evolution that fed on two structural elements, namely the 'asymmetrical' constitutional architecture' of EMU and the circular logic between centralised monetary policy and decentralised economic policies. ${ }^{35}$ How such elements interplayed and influenced each other during the European debt crisis has been subject of in-depth studies and research. What is certain is that those elements intensified the need for a supranational management of economic interdependences and shared responsibilities and contributed to making the Euro Group a crucial cog in that management. ${ }^{36}$

Should there be any doubts, here is the Euro Summit Statement of 26 October 2011: 'The Eurogroup will, together with the Commission and the $\mathrm{ECB}$, remain at the core of the daily management of the euro area' ${ }^{37} \mathrm{I}$ believe this state of affairs provides sufficient grounds for viewing the Euro Group as part of the European institutional framework. ${ }^{38}$ To be sure, claiming otherwise would have required arguments more powerful than those offered

32 Craig (n. 29), 235.

33 Baratta (n. 29), 502; Craig (n. 29), 244.

34 Decision of the Heads of State or Government, meeting within the European Council, concerning a new settlement for the United Kingdom within the European Union, OJ 2016 C $69 \mathrm{I} / 3$.

35 Baratta (n. 29), 496.

36 Hofmann and Pantazatou (n. 29), $15 \mathrm{f}$. and $22 \mathrm{f}$.

37 See the Euro Summit Statement as included in General Secretariat of the Council, 'Rules for the organisation of the proceedings of the Euro Summits', (2013), 13-24 (para. 32).

38 A similar reading is also shared by the Council's agent in Chrysostomides E Co., Alberto de Gregorio Merino, at least in his individual capacity. See Eugenia Dumitriu Segnana and Alberto de Gregorio Merino, 'EU Institutions Representing Member States' Governments' in: Fabien Amtenbrink and Christoph Herrmann (eds), The EU Law of Economic and Monetary Union (Oxford: Oxford University Press 2020), 428-455 (446 ff). See also Francesco Munari, 'La Corte di giustizia e i nuovi soggetti istituiti nel quadro dell'Unione economica e monetaria' in: Liber Amicorum Antonio Tizzano: De la Cour CECA à la Cour de l'Union: le long parcours de la justice européenne (Torino: Giappichelli 2018), 661-671 (662). 
by the Court, which instead limited itself to stating that the Euro Group was originally conceived as an intergovernmental body (more than twenty years ago); and to apodictically adding that the Treaty of Lisbon did not change this fact 'in the slightest'. ${ }^{39}$ However difficult the position of the Court was the Euro Group admittedly is one of the most powerful yet least intelligible bodies of the European institutional framework - a deeper engagement with the political reality of the Euro Group was necessary. ${ }^{40}$

\section{Informality and the Lack of Own Competences}

To shield the Euro Group from non-contractual liability, the Court offers two further arguments. In particular, the Court affirms that the Euro Group is characterised by its informality and does not have any competences of its own. Although the Court treats these two arguments separately, ${ }^{41}$ they are actually connected and worth examining together. Indeed, one of the main features of European informal bodies is their lack of competences or, to be more exact, their lack of final decision-making powers. ${ }^{42}$ According to its 'Working Methods', for example, the Euro Group 'is an informal body and therefore it does not adopt any formal conclusions'. ${ }^{43}$ Now, the main problem with the Court's arguments is their strangely formalistic flavour. In particular, the Court seems to disregard that the informal nature of a body is compatible with high levels of institutionalisation and autonomy, which may in turn result in the occasional production of legal effects. This circumstance, I believe, should have led the ECJ to decide differently.

As regards the institutionalisation of the Euro Group, here are some relevant points. The existence of the Euro Group is indicated in EU primary law. In particular, the Treaties comprise provisions concerning its mandate, its composition (including the participation of the Commission and the ECB), and the election of its president. Details about the functioning of the Euro Group are laid down in a set of official 'Working Methods' ${ }^{44}$ Information on its activities and the activities of its president is made public on the

39 Following the arguments put forward by the Council, the Court argues that the Euro Group was not established by the Treaties, as requested by its case-law on Art. 340 TFEU, but merely recognised by them. See Council of the European Union (n. 11), paras $13 \mathrm{ff}$. and 30.

40 ECJ, Chrysostomides, opinion of AG Pitruzzella (n. 3), para. 4.

41 ECJ, Chrysostomides (n. 1), para. 89.

42 See also ECJ, Chrysostomides, opinion of AG Pitruzzella (n. 3), para. 86.

43 Euro Group, 'Working Methods of the Eurogroup', (ECFIN/CEFCPE(2008)REP/ 50842rev 1, 3 October 2008), 6.

44 Euro Group (n. 43). 
website of the Council, where the Euro Group has its own dedicated section. The output of its meetings 'shall be communicated systematically and visibly'. ${ }^{45}$ The president of the Euro Group has, on several occasions, represented the Eurozone on the international plane - Art. 138 TFEU speaks of a 'unified representation [of the Eurozone] within the international financial institutions and conferences' ${ }^{46}$ All these features, including the election of its president by majority, testify to a fairly high level of institutionalisation, which distinguishes the Euro Group from, e. g. a meeting of the Representatives of the Governments of the Member States. Therefore, when the ministers of the Eurozone sit on the Euro Group, they are members of a body in its own right rather than just national politicians collectively exercising the powers of the Member States. ${ }^{47}$

Furthermore, and contrary to the findings of the Court, the informality of the Euro Group is not supposed to preserve the role of the Council in economic matters. In the European institutional framework, informality aims to facilitate the aggregation of preferences through consensus-based processes ${ }^{48}$ especially in the context of policy coordination. ${ }^{49}$ Informal bodies may therefore enjoy high levels of autonomy vis-à-vis those institutions for which they do preparatory work; and the Euro Group certainly enjoys such an autonomy. This is confirmed, for example, by the president's term of two-and-a-half years (as distinguished from the six-month rotating presidency of the Council), ${ }^{50}$ the formulation of its own work programmes, and the growing relevance of Euro Group meetings in 'inclusive format' (ministers of the Eurozone plus ministers of the other Member States). ${ }^{51}$ Especially this last point, which highlights the gravitation of the non-Eurozone Member States to the Euro Group, bears witness to the emergence of a powerful, self-contained decision-making body. In addition, and contrary to what the Court states, the independence of the ECB from the Euro

45 Euro Group (n. 43), 6.

46 Baratta (n. 29), $518 \mathrm{ff}$.

47 In similar terms, Baratta (n. 29), 509. As regards the meetings of the Representatives of the Governments of the Member States, see, e.g. ECJ, Représentants des Gouvernements des États membres v. Sharpston, order of 10 September 2020, case no. C-424/20 P(R), ECLI:EU: C:2020:705, para. 26.

48 On the features of European informality, Giacomo Rugge, Trilogues: The Democratic Secret of European Legislation (Cambridge: Cambridge University Press, forthcoming), ch. 4.

49 Regarding the important role of informality in the context of policy coordination in federal polities, see also Thomas O. Hueglin and Alan Fenna, Comparative Federalism: A Systematic Inquiry (2nd edn, Toronto: University of Toronto Press 2015), $238 \mathrm{ff}$.

50 Euro Group (n. 43), 4.

51 Diane Fromage, 'Towards Increasing Unity and Continuing Executive Predominance Within the E(M)U Post-COVID?', Legal Issues of Economic Integration 47 (2020), 385-408 (387). 
Group is not safeguarded through the informal nature of that body, but through a legal provision of Protocol (No 14). Art. 1 of that Protocol provides that the ECB 'shall be invited to take part in [the Euro Group] meetings'. As a result, the ECB is free to decide on a case-by-case basis whether its participation might dent its independence and decline the invitation, as appropriate.

The upshot of these observations is that, due to its significant institutionalisation and autonomy, the Euro Group has become an influential, authorityexercising body. In these circumstances, it cannot be excluded that the Euro Group may occasionally bring about acts or conduct capable of producing harmful effects. The Court should have taken this possibility into account and kept the door open for future possible actions against the Euro Group. Actions for damages have, according to Art. 41 para. 3 CFR, the quality of a fundamental right and should therefore enjoy a presumption of admissibility. This is even more so since such claims are usually unlikely to succeed in the merits, and a more liberal approach as to their admissibility may at least make them a vehicle for specific interests vis-à-vis the Union institutions. ${ }^{52}$ In addition, the chance of the CJEU being inundated with liability claims seems rather small. The last available figures show that, in 2019, individuals lodged with the General Court 24 actions for damages (which included both contractual and non-contractual liability) out of a total of 939 actions, accounting for no more than $2.55 \%$ of the GC's docket. ${ }^{53}$

Finally, it is difficult to avoid the impression that, by focussing on whether the Euro Group is an 'institution' under Art. 340 TFEU, the Court has lost sight of the real issue at stake. This was to decide whether the acts and conduct of the Euro Group may be attributed to the Union for the purposes of non-contractual liability. It is indeed worth repeating that, from a substantive viewpoint, it is only the Union - and not its institutions or bodies which may incur that liability. ${ }^{54}$ This is also why the EU judicature has usually followed a very flexible approach when it comes to applications for damages that do not specify the institution or body against which they are directed. ${ }^{55}$ Importantly enough, Art. 340 TFEU speaks not only of 'institutions' but also of 'servants in the performance of their duties'. It is therefore surprising to read in the Council's appeal that if the Court had included the Euro Group within the scope of Art. 340 TFEU, 'there would [have been]

52 Jacob and Kottman (n. 25), para. 29.

53 Court of Justice of the European Union, 'Annual Report 2019: Judicial Activity', (February 2020), 285.

54 See, e.g., ECJ, European Ombudsman v. Frank Lamberts, judgment of 23 March 2004, case no. C-234/02 P, ECLI:EU:C:2004:174, para. 48.

55 Lenaerts, Maselis and Gutman (n. 25), 496. 
no justification why other deliberative instances, preparatory committees or even the General Secretariat of the Council could not be named as separate defendants in actions under Article 340 TFEU'. ${ }^{6}$ There is indeed no doubt that those bodies may attribute non-contractual liability to the Union. The question whether they can be regarded as separate defendants is largely secondary.

So much for the nature and role of the Euro Group in the European institutional framework.

\section{The Principle of Effective Legal Protection}

As indicated above, the Court rejects the idea that excluding the Euro Group from the scope of Art. 340 para. 2 TFEU may create a gap in the fundamental rights protection system as provided for by EU law. To substantiate its position, the Court points out that individuals may always file 'an action to establish non-contractual liability of the European Union against the Council, the Commission and the ECB in respect of the acts or conduct that those EU institutions adopt following' those political agreements concluded within the Euro Group. ${ }^{57}$ However, these alternatives do not offer as effective a legal protection as the Court maintains, leaving a number of procedural gaps in the European system of judicial remedies. Here are some examples.

First, the Euro Group might go public with a communication, a statement, or a press release that produces (harmful) effects in itself, without needing any follow-up measures. Recent history has indeed taught us that such an occurrence is not unlikely. As it turns out, even a single line in a speech may have meaningful repercussions for legal orders and individuals, especially when it comes to economic and monetary matters. ${ }^{58}$ In such a case, and following the Court's findings in Chrysostomides E Co., natural and legal persons would be left without judicial protection. Secondly, the Euro Group might reach a political agreement as part of a broader decision-making process, which is supposed to end with the adoption of a definitive act or conduct by other institutions. In such a case, two scenarios are possible: Either the institutions intervening 'downstream' are free to depart from the

56 Council of the European Union (n. 11), para. 42.

57 ECJ, Chrysostomides (n. 1), para. 89.

58 The reference is, of course, to Draghi's 'whatever it takes' speech at the 2012 Global Investment Conference in London. See European Central Bank, 'Verbatim of the remarks made by Mario Draghi: Speech by Mario Draghi, President of the European Central Bank at the Global Investment Conference in London 26 July 2012', (26 July 2012). 
Euro Group's position; or they are de facto bound by that position - and intervene just to rubber-stamp it. Especially in this second case, the joint reading of Art. 41 para. 3 and Art. 47 CFR calls for as timely a protection as possible. The sooner the protection intervenes the better, not least in the interest of the EU. Indeed, the adoption of definitive acts or conduct may take up time, thereby engendering significantly higher costs for the Union's coffers in case of future compensation.

Even the Ledra judgment, important as it is, cannot offer a suitable alternative remedy in the two cases outlined above. On the one hand, the judgment concerns only the damages caused by the Commission and the ECB when exercising the tasks attributed to them by the ESM Treaty. It is therefore of little or no avail when it comes to redressing damages caused by the Euro Group in situations other than those concerning the adoption of conditionality-related measures. On the other hand, the non-contractual liability based on the Ledra judgment risks intervening too late, as it becomes actionable only when the Commission does not 'refrain from signing a memorandum of understanding whose consistency with EU law it doubts'. ${ }^{59}$ As it stands, that liability covers neither those damages that occur between the negotiations in the Euro Group and the signing of a draft MoU by the Commission, nor those damages that may still result in case of final refusal of the Commission to sign a draft MoU.

As recalled, the Court also suggests that individuals may base their actions for damages on those Council decisions that endorse the outcome of conditionality negotiations. ${ }^{60}$ According to Art. 7 Regulation 472/2013/EU, which forms part of the 'Two-pack' legislation, ${ }^{61}$ the Council is called upon to approve the macroeconomic adjustment programmes that result from the negotiations between the requesting Member States and the 'troika'. ${ }^{62}$ This solution, however, does not seem to pay due attention to the (rather problematic) Court's case-law on the 'margin of discretion'. This case-law concerns the damages that derive from national provisions implementing EU measures; and it provides that the institutions of the Union may incur non-contractual

59 ECJ, Ledra (n. 5), para. 59.

60 ECJ, Chrysostomides (n. 1), para. 94.

61 On the 'Two-pack' legislation, Michael Ioannidis, 'EU Financial Assistance Conditionality after "Two Pack"', HJIL 74 (2014), 61-104 (89-91), who argues that there are doubts as regards the appropriateness of the legal bases chosen for the adoption of that legislation (i. e. Art. 136 TFEU, read in conjunction with Art. 121 para. 6 TFEU).

62 Regulation 472/2013/EU of 21 May 2013 on the strengthening of economic and budgetary surveillance of Member States in the euro area experiencing or threatened with serious difficulties with respect to their financial stability, OJ 2013 L 140/1. As regards the endorsement of the outcome of conditionality negotiations by means of a Council decision as a distinguishing feature of European conditionality, Ioannidis (n. 61), $93 \mathrm{f}$. 
liability only when the EU measures leave no discretion to the national authorities as to the provisions to be adopted.63 Unfortunately, Council decisions pursuant to Art. 7 Regulation 472/2013/EU tend to be open-ended, 'simply copy[ing] the most important conditions included in the Memorandum' ${ }^{64}$ And this makes it easy for the Council to claim that national authorities enjoy genuine discretion at the time of implementation - as the Council successfully did in its cross-appeal in the case at hand. ${ }^{65}$ What is more, Art. 7 Regulation 472/2013/EU is so worded as to formally allocate 'primary responsibility for conditionality to the Member State concerned'. ${ }^{66}$ It refers, for example, to the 'macroeconomic adjustment programme prepared by the Member State requesting financial assistance'. ${ }^{67}$ So, when the Court suggests challenging those Council decisions that endorse the outcome of conditionality negotiations, it is one of the two: It is either implying a partial revirement of its case-law, to the effect that it will always consider those decisions amenable to scrutiny, regardless of the level of discretion they leave to national authorities; or it is overlooking that such a solution carries within it the seeds of its own failure.

It must also be recalled that seeking compensation for damages deriving from general measures of economic nature has always been an uphill strug-

63 ECJ, Étoile commerciale and CNTA v. Commission, judgment of 7 July 1987, case no. C89/86, ECLI:EU:C:1987:337, para. 18. It bears noting that the ECJ has also taken a more restrictive approach than the one reported above. See, e.g. ECJ, Interagra v. Commission, judgment of 10 June 1982, case no. 217/81, ECLI:EU:C:1982:222, para. 9 f., in which the Court dismissed an action for damages, even though the harmful act was adopted by national authorities in application of EU provisions that left no genuine discretion as regards the implementing measures. On this case-law, see also Lenaerts, Maselis and Gutman (n. 25), $501 \mathrm{ff}$.

64 Ioannidis (n. 61), 72 and fn. 49.

65 In its cross-appeal, the Council raised two pleas. First, it maintained that '[i]ndependently from the existence of the Council decision, the Republic of Cyprus had adopted and would have to maintain or continue implementing the harmful measures, since they were included in the MoU bilaterally signed between the Republic of Cyprus and the ESM. The requirement to maintain and continually implement the harmful measures could not be attributed to the Council but is attributable only to the Republic of Cyprus in the context of its negotiations with ESM following its own decision to request ESM financial assistance'. Secondly, and in the alternative, the Council argued that 'Cyprus retained a large margin of discretion on the manner to [implement that decision] and even, on not [implementing] it'. See Council of the European Union, 'Cross-appeal by the Council in Case C-603/18 P', (SGS18/10300, 19 December 2018), para. $24 \mathrm{ff}$. The Court rejected the first plea, while upholding the second. In particular, the Court stated that the Council decision was vague enough to allow the Cypriot authorities for a margin of discretion during the implementation stage. The problem with these findings (and the corresponding case-law) is that they do not seem to consider different degrees of discretion. Therefore, even the smallest margin of discretion enjoyed by the national authorities is enough to exonerate the EU from non-contractual liability. See ECJ, Chrysostomides (n. 1), para. $106 \mathrm{ff}$.

66 Ioannidis (n. 61), 92.

67 Emphasis added. 
gle. ${ }^{68}$ In Zuckerfabrik Schöppenstedt v. Council, the Court famously stated that ' $[\mathrm{w}]$ here legislative action involving measures of economic policy is concerned, the Community does not incur noncontractual liability for damage suffered by individuals as a consequence of that action [...] unless a sufficiently flagrant violation of a superior rule of law for the protection of the individual has occurred' ${ }^{69} \mathrm{~A}$ few years later, this maxim was confirmed in HNL v. Council and Commission, where the ECJ maintained that 'public authorities can only exceptionally and in special circumstances incur liability for legislative measures which are the result of choices of economic policy. This restrictive view is explained by the consideration that the legislative authority [...] cannot always be hindered in making its decisions by the prospect of applications for damages whenever it has occasion to adopt legislative measures in the public interest which may adversely affect the interests of individuals' ${ }^{70}$ Against this backdrop, no wonder the General Court in Chrysostomides $\mathcal{E}$ Co. rejected the actions in the merits. In fact, these circumstances would have spoken in favour of loosening the admissibility criteria of the actions under Art. 340 para. 2 TFEU, shifting the focus of judicial review from questions of admissibility to questions of substance.

A final point is in order. Indeed, the CJEU is sending haphazard signals about the role and function of the action for damages in the EU's 'complete system of legal remedies'. In some instances - as in the case at hand - the CJEU has adopted an unreasonably restrictive approach. In other instances, instead, it has adopted an extremely generous one, going well beyond the letter of the Treaties. In Bank Refah Kargaran v. Council, for example, the Court was called upon to adjudicate on the admissibility of actions for damages against Common Foreign and Security Policy (CFSP) decisions providing for restrictive measures against natural or legal persons. Although the Treaties are unequivocal in excluding the Court's jurisdiction over CFSP matters (save for two exceptions unrelated to the matter at hand), the Court found otherwise. Relying on a broad palette of Treaty provisions, including those concerning its general competence (Art. 19 TEU), the rule of law as founding value of the Union (Art. 2 TEU), and the right to an effective judicial protection (Art. 47 CFR), the Court stated that 'the necessary coherence of the system of judicial protection provided for by EU law requires that, in order to avoid a lacuna in the judicial protection of the natural or legal persons concerned, the Court of Justice of the European Union must

68 In this sense, see also Munari (n. 38), 664.

69 ECJ, Zuckerfabrik Schöppenstedt v. Council, judgment of 2 December 1971, case no. C5/71, ECLI:EU:C:1971:116, para. 11.

70 ECJ, HNL v. Council and Commission, judgment of 25 May 1978, case no. C-83/76, ECLI:EU:C:1978:113, para. 5. 
also have jurisdiction to rule on the harm allegedly caused by restrictive measures provided for in CFSP Decisions'. ${ }^{71}$ Whatever the reasons behind these haphazard signals, ${ }^{72}$ the CJEU should develop a more coherent doctrine with regard to liability claims. The current situation indeed risks undermining the principle of legal certainty on which a system of judicial remedies is supposed to rest.

\section{Conclusion}

The judgment in Chrysostomides $\mathcal{E}$ Co. is the latest development in a long-running dispute over the means to ensure effective protection against austerity measures adopted in the context of European financial assistance activities. The judgment must be praised to the extent that it recognised and protected the Euro Group as a body for 'fireside chats' and the attainment of compromise. It must however be criticised for having misrepresented the role of the Euro Group in the field of economic policy coordination. Given the Euro Group's political influence (and its lack of transparency and accountability), the EU must have means and instruments that enables it to oversee such a powerful and controversial body. Against this backdrop, maintaining that the Euro Group is outside the framework of the Treaties - and, therefore, beyond the reach of the EU judicature - testifies to a troubling disconnection from the political reality of EMU.

To date, individuals adversely affected by austerity measures have the following options. First, they may bring legal actions against national measures implementing an MoU before national courts for violation of domestic law. Secondly, they may initiate proceedings before national courts against the ESM, i.e. an intergovernmental organisation operating under public international law. Thirdly, they may file actions for damages against the Commission and the ECB in line with the Ledra case-law, if these fail to comply with the duties bestowed upon them by the Treaties (e.g. the supervisory obligations of the Commission as 'guardian of the Treaties'). Fourthly,

71 ECJ, Bank Refah Kargaran v. Council, judgment of 6 October 2020, case no. C-134/19 P, ECLI:EU:C:2020:793, para. 39. On this judgment, Francesco Bestagno, 'Danni derivanti da misure restrittive in ambito PESC e azioni di responsabilità contro l'UE', Eurojus 7 (2020), 280-289; Maria Eugenia Bartoloni, “"Restrictive Measures” Under Art. 215 TFEU: Towards a Unitary Legal Regime? Brief Reflections on the Bank Refah Judgment', European Papers 5 (2020), 1359-1369.

72 See, e.g. Bestagno (n. 71), $287 \mathrm{f}$., who argues that the Court's findings in Bank Refab might also be seen as an attempt to blur the peculiarities of the CFSP legal regime vis-à-vis other policies of the Union, in light of a possible accession to the European Convention on Human Rights. 
they may file actions for damages against the Council in relation to decisions based on the 'Two-pack' legislation. Finally, they may urge national courts to ask the ECJ for a preliminary ruling of validity on those Council decisions. Although numerous, I hold all these options for inadequate. The problem is that individuals cannot as yet rely on direct actions (with reasonable chances of success and erga omnes effects) against austerity measures negotiated between their governments and the other Member States.

The notion of 'systemic risk' has been used to justify a greater - and, to my eyes, appropriate - intervention of the EU in national economic matters. Sometimes, however, when it comes to ensuring political scrutiny and judicial redress, one has the impression that those systemic risks suddenly become just an issue of national policy. Given the missed incorporation of the ESM Treaty into the EU law framework, the ECJ should have seized the chance to acknowledge the influential role of the EU in the management of economic and financial crises. By so doing, it would have achieved a twofold objective. On the one hand, it would have indicated the EU's willingness to bear its share of political responsibility. On the other hand, it would have clarified to supranational and national decision-makers that the EU judicature is not hesitating to embrace the ongoing transformation of the European economic constitution and to adapt the system of judicial remedies accordingly. Hence the question: What might this adaptation look like?

The heart of the matter is the relationship between the action for annulment and the action for damages. If the latter is meant to compensate for the strictures of the Plaumann doctrine, ${ }^{73}$ the CJEU cannot avoid embracing a more liberal approach in terms of admissibility, especially since the action for damages does not have erga omnes effects and places a hefty burden of proof on the applicants. Should the CJEU go down this path, it should also ensure that the action for damages be directed against those European institutions and bodies that are actually responsible for the content of the harmful acts or conduct (i.e. the real decision-making loci), offering as timely a judicial protection as possible.

I however advocate for a different solution; one that prioritises the action for annulment. As convincingly argued, this is the action which is best suited to resolving issues of validity of general measures. ${ }^{74}$ This would require the Court to change its case-law on the notion of 'individual concern', as referred to in Art. 263 para. 4 TFEU. To stem an excessive inflow of applications, the Court could also interpret Art. 340 TFEU in such a way as to exclude the

73 Lenaerts, Maselis and Gutman (n. 25), 493.

74 ECJ, Unión de Pequeños Agricultores v. Council, opinion of AG Jacobs of 21 March 2002, case no. C-50/00 P, ECLI:EU:C:2002:197, para. 63. 
non-contractual liability of the EU for general measures. Such a position would not be outlandish, since other European legal orders (e.g. Germany and Italy) exclude any non-contractual liability for legislative wrongdoing. To that end, the Court could argue 'in accordance with the general principles common to the laws of the Member States', as expressly provided for by Art. 340 TFEU. ${ }^{75}$

I have no illusions about the possibility of seeing such a change happen in the near future. The Court must be aware, though, that many natural and legal persons are resorting to other international tribunals in order to have their complaints heard, with all the issues of fragmentation and conflicting decisions that may follow. For instance, about 1,000 depositors and bondholders of Laïki and Bank of Cyprus initiated arbitration proceedings at the International Centre for Settlement of Investment Disputes (ICSID), which are now moving to the merits despite Cyprus' intra-EU jurisdictional objection. ${ }^{76}$ The chances of success are slim, as two previous tribunals at the Stockholm Chamber of Commerce and at ICSID rejected similar claims. Claimants may feel, though, that these proceedings are at least not " blindly" excluding [them] without consideration of the merits of the argument they put forward'. ${ }^{77}$ Perhaps, the fact that the leading defendant in the case at hand was Dr. Kypros Chrysostomides, a politician and lawyer from Cyprus with ambiguous ties to Paul Manafort (Trump's former electoral campaign team leader and a convicted felon), may have shed a negative light on the applications. ${ }^{78}$ It is however a pity that the Court did not reject the Council's appeal. By so doing, it would have left no doubt that there is still a judge in Luxembourg, 'alive and kicking'.

75 As regards Germany, see Bundesgerichtshof, judgment of 29 March 1971, III ZR 110/68, Juris para. $16 \mathrm{f}$. In legal scholarship, Hans-Jürgen Papier and Foroud Shirvani, 'Art. 34 GG' in: Theodor Maunz and Günter Dürig (eds), Grundgesetz: Kommentar (München: C. H. Beck 2020), para. 195-199. As regards Italy, see Cass. Civ., Sez. III, judgment no. 23730 of 22 November 2016. In legal scholarship, Alessandro Pizzorusso, 'La responsabilità dello Stato per atti legislativi in Italia', Il Foro Italiano 126 (2003), 175-183.

76 ICSID, Theodorus Adamakopoulos and others v. Republic of Cyprus, decision on jurisdiction of 7 February 2020, case no. ARB/15/49.

77 ECJ, Unión de Pequeños Agricultores, opinion of AG Jacobs (n. 77), para. 66.

78 Nicholas Confessore and Barry Meier, 'How the Russia Investigation Entangled Rick Gates, a Manafort Protégé’, The New York Times (16 June 2017). 